\title{
Ectonucleotide Pyrophosphatase/Phosphodiesterase Family Member 3
}

National Cancer Institute

\section{Source}

National Cancer Institute. Ectonucleotide Pyrophosphatase/Phosphodiesterase Family

Member 3. NCl Thesaurus. Code C147048.

Ectonucleotide pyrophosphatase/phosphodiesterase family member 3 (875 aa, 100 $\mathrm{kDa}$ ) is encoded by the human ENPP3 gene. This protein plays a role in the cleavage of phosphodiester and phosphosulfate bonds. 